\title{
Differential Leukocyte Count
}

National Cancer Institute

\section{Source}

National Cancer Institute. Differential Leukocyte Count. NCI Thesaurus. Code C98493.

A hematologic procedure for the evaluation of the qualitative and quantitative

characteristics of the white cells in peripheral blood smears and bone marrow aspirates. 